\title{
Policy Related Strategies to Curb Examination Malpractices among Undergraduate Students in Kenyan Universities
}

\author{
Stellah J. Keter*
}

PhD Student, Department of Educational Management and Policy Studies, School of Education, Moi University, Eldoret, Kenya

DOI: $10.36348 /$ jaep.2021.v05i01.001

| Received: 30.09 .2020 | Accepted: 16.10.2020 | Published: 22.01.2021

*Corresponding author: Stellah J. Keter

\section{Abstract}

Universities have formulated policies on the execution of examinations but, examination malpractices are still witnessed. Eradicating examination malpractices needs engagement in enquiry driven reform and probing teaching and learning and schooling realities to highlight what to be done and how. The study's main purpose was to evaluate policy-related strategies to curb examination malpractices among undergraduate students in Kenyan universities. The theory of Planned Behaviour guided the study. The sample size comprised of 450 participants; lecturers, dean of students (DoSs), heads of departments (HoDs), examination officers(EOs) and undergraduate students from the selected universities in Kenya. Proportionate stratified sampling was used to select lecturers and students, simple random sampling for HoDs and further purposive sampling for DoSs and EOs. The study adopted a mixed methods design and data was collected using questionnaires, interview schedules, focused group discussions and document analysis. A pilot study was carried out to check the reliability of the research instruments. Data was analysed using both qualitative and quantitative statistics and results interpreted using frequencies, standard deviations, means and percentages. Pearson's Correlation Coefficient was employed to determine relationships between variables. The study findings on the existing policies related to examination malpractices have positive and statistically significant effect on curbing examination malpractices $(r=0.669 ; \mathrm{p}<0.05)$. The existing policies related to the examination malpractice have great effect on the degree to which students can practice examination cheating. Policies related to examination malpractices among undergraduate students include attaining minimum mark of 40 makes students engage in examination malpractices, overcrowded examination rooms which tempt students to cheat in examination, low lecturer/student ratio and lack of proper students' records make students to lie. Universities are better advised to adopt good policies that can curb examination malpractices. The study recommended that academic departments to review the minimum pass mark since the policy of minimum mark encourages students to be lazy and definitely engage in examination malpractices. It is also recommended that DVC and the Registrar in charge of academics to make spot checks during examination as a way of monitoring what is happening during this process of examinations.

Keywords: Existing Policies, Examination malpractice, Curbing, Undergraduate Students and Kenyan universities.

Copyright $($ ) 2021 The Author(s): This is an open-access article distributed under the terms of the Creative Commons Attribution 4.0 International License (CC BY-NC 4.0) which permits unrestricted use, distribution, and reproduction in any medium for non-commercial use provided the original author and source are credited.

\section{INTRODUCTION}

\section{Background of the Study}

Examination policies entail guidelines regulating the administration of examination and the conduct of students (undergraduates/ postgraduates) examinations. The public policy considerations by the appointed authorities included; placing the courts into an inappropriate situation of interfering with the everyday policies that are entrusted to a school authority, a surge of cases filling the courts and the putting of undue burden upon the limited resources of a school [1]. In an investigation completed in North America it was seen that schools obsessed with performance encouraged cheating and the classrooms that emphasized high grades and test scores may also drive students to cheat. They likewise recognized examination timetabling, poor supervision and a badly organized course as other reasons for examination dishonesty [2].

As indicated by Russo [3], the first instance of examination malpractice in the U.S. was heard in 1976, where the student sued the school authority for neglecting to take part effectively in giving satisfactory guidance, direction, or supervision in basic skills, for example, reading and writing. The Court completely reasoned that there was no broad obligation of care owed by teachers to students in regard to education results. The following U.S. case was heard where a 
Stellah J. Keter., J Adv Educ Philos, Jan, 2021; 5(1): 1-15

comparative charge to the prior case was made [3]. While the case against the school administration was not successful because of policy deliberations, the Court of Appeals of New York noticed that a suit for educational malpractice could be made to fit the traditional negligence principles. They additionally offered the remark that if specialists, lawyers, architects, engineers and different professionals are accused of an obligation attributable to the open that they serve, one might say that nothing in the law blocks comparative treatment of professional educators. This remark naturally caused horror among educators [4].

In China, reports of college cheating have reduced after some time, academic qualification is a huge predictor of cheating in college. In Israel the situation is also similar as Kasler, Hen, and Sharabi [5], discovered that most of the students viewed academic misconduct as a serious issue. The individuals who announced high on academic misconduct were concentrated among the individuals who had not done national service, studied in the science faculty and were Arabic-speaking students.

In Africa, there is a necessity to prevent examination malpractices in schools because they threaten education's important mission and goal. Findings from studies undertaken by various scholars in Nigeria revealed that examination malpractices were not a new phenomenon in that country and affirmed the first examination malpractice which was believed to have been reported in 1914 during the Cambridge Local Examination. It was reported that papers were leaked before the scheduled date of examinations. However, it was worrisome a trend that started slowly has reportedly become very pronounced not only in Nigeria but across the globe. Besides, cases of examination malpractices have become more advanced and sophisticated with time [6].

Likewise in Zimbabwe, the level of students' engagement in examination malpractice in higher education has gotten progressively stressing, tricky and threatening to the prosperity of the Zimbabwean educational system [7]. Question paper leakages, careless impersonation in examination centres, the urgency of school owners, paying off examination officials and parents purchasing leaked papers for their kids prior to the commencement of examinations are the major forms of examination malpractices and fraud. Examination malpractice and fraud ought not to be underestimated if academic institutions need to seek the best practices in examination management. Such events at last damage public confidence in the validity and authenticity of the examinations and results [7].

Udim, Abubakar and Essien [8] assessed policy-related strategies to curb examination malpractices among undergraduate students and they established that examination malpractices happen both inside and outside the examination halls. It is executed by students, staff and other external agents previously, during and even after examinations. Numerous strategies applied to curb examination malpractices within the university system have proven ineffective. New devices for executing examination malpractices quickly and greatly making such strategies look as though they are tending to the symptoms rather than the root causes. Udim et al., [8] explained that the situation might not be unconnected with the fact that student culprits are usually targeted by these strategies, brushing aside the contributory roles of other university members in the eventual act.

\section{Statement of the Problem}

Examination malpractices have become rampant especially among undergraduate students in Kenyan universities. My personal interaction with students from various universities indicates that rampant cheating in examination is a norm and remains a major problem. As one listens to students from institutions of higher learning converse there is no doubt that examination malpractices exist in an alarming rate. This is evidenced by presence of various forms of malpractices during examinations and continuous assessments as the lecturers invigilate and mark the examinations. Further interaction with stakeholders in various forums, in many circumstances employers complain of varsity students' incompetence and they prefer to employ diploma holders because they feel they are adequately prepared than their counterpart undergraduate students. This act of cheating is a bad habit that appears to have gone past university examinations regulations and policies set up by different institutions of learning. A significant number of the occurrences of cheating in examinations are sometimes attributed to various factors that require to be established. The persistent occurrence of examination malpractice has been a major concern to educational stakeholders. Common observations have shown that there is mass cheating in all the universities both public and private. Nothing concrete has been done to reduce the problem except the cancellation of results or the withholding of results in certain courses. However, despite various efforts and measures put in place by various universities, examination malpractices are still increasing. University authorities seem to be in dilemma as cases of examination malpractice increase day by day. This undermines the quality of graduands and their preparation into the job market, which results to the loss of credibility and purpose of examinations. Therefore there is dire need to policy related strategies to curb the examination malpractices in institutions of higher learning if quality of grandaunts is to be upheld.

\section{Research Objective}

The objective of the study was to evaluate policies related to examination malpractices among undergraduate students in Kenyan universities. 
Stellah J. Keter., J Adv Educ Philos, Jan, 2021; 5(1): 1-15

Research Hypothesis

$\mathbf{H}_{\mathbf{0 2}}$ : There is no statistically significant relationship between the existing policies related strategies and examination malpractices among undergraduate students.

\section{LITERATURE REVIEW \\ Theoretical Review \\ Theory of Planned Behaviour}

This study was guided by Ajzen's models of the Theory of Planned Behaviour [9]. This theory was developed from Fishbein and Ajzen's [10] theory of reasoned action. As indicated by Agata, Abby, Joana, Daniela, Hapon, Anna and Denis 2015, the theory contemplates that individuals intend to behave in a particular manner out of the attitude towards that behaviour, for example from suppositions with respect to the way in which others will react to the manner an individual behaves. The Theory of Planned Behaviour (TPB), which defines the components that add to a person's choice to carry on in a particular way, has been recently utilized in researches that sought to establish the determinants of academic dishonesty and academic misconduct discussed by Alleyne and Phillips [11] as cited by Agata et al., [12].

Revelations from O'Neill and Pfeiffer [13], indicated that the apparent probability of being discovered cheating is the main factor that accounts for behavioural action than the university policies regarding academic dishonesty. This fact is attested by findings by Keter [14] which observed that majority of the students disagreed respectively that there are no severe penalty for malpractices. This implies that students continue to engage in academic malpractices despite the penalties that are in place. Whereas, Carrol [15] discovered that enhanced punishment for academic misconduct has little relationship with cheating behaviour since students with varied interpretations of what the seriousness of the punishment for cheating were all liable to cheat since they believed that increased punishments were insignificant since their cheating could never be found.

In spite of the general accomplishment of the TPB, the conceptualization of PBC has been disputed. An indicator of this dispute is the inconsistency in the labels used for the PBC components. Significantly, a difference in definitions and operationalization may contemplate that empirical research is precedent to theory in this area. As of late, many PBC studies have tended to the likelihood that PBC is a multidimensional construct as seen in Trafimow, Sheeran, Conner and Finlay's [16] diagram. On another related line of enquiry, scientists have evaluated the discriminant legitimacy of PBC. In particular, some scientists have inquired whether PBC is not just an interrelated way of measuring attitude [17, 18]. While some have had doubts about it and differentiated from intentions [19, 20].
Having discovered what intentions are and how they strongly relate to behaviour, it can be concluded that intentions may be unreasonable or irrational, hence the time has come to direct our concentration toward detailed investigation and to detect when and why intentions are not converted into behaviour. The encounter between intentions and the physical, social or psychological constraints that keep people from their realization is a long-standing subject of theoretical inquiry in sociology [21]. Stone et al., [22] point to a wide scope of areas that, upon more profound examination, may give productive responses to these questions. This interest isn't conflicting with the rich proof that, in the total, aims and practices are profoundly related.

The aspect of the theory of planned behaviour is appropriate for this study since the intentions of examination malpractices towards academic excellence by students is well reasoned against consequences of failing in examination by the same students which are condemned by the parents and the school administration. The intentions to behave in a particular way results from attitudes towards that behaviour and from subjective norms, for example the manner in which students practice examination malpractice is respond to the behavior expected by the parents to academically excel without limitations in their performance. In concussion, the theory explains the factors that influence a person's choice to act in a specific manner and which have been previously used in research concerning the determinants of academic dishonesty and academic misbehaviour.

\section{LITERATURE REVIEW}

\section{Existing Policies on Examination Execution in Universities}

Universities have formulated policies on execution of examinations but, examination malpractices are still witnessed. Patrick [23] examined Non-formal Education and the Promise of Development. Results discussed that in view of the previous mention, efforts by examining bodies and their elaborate policies though formidable enough seem to be quite inadequate. Tambuwal [24] asserts that candidates produced in the system of examination malpractice will themselves grow up and become teachers or examination officers who will not see anything wrong with the sophisticated and high class examination fraud which only favours certificated illiterates. Eradicating examination malpractices needs engagement in enquiry driven reform and probing teaching and learning and schooling realities so as to highlight what to be done and how.

Otieno [25] assessed effectiveness of Kenya National Examinations Council (KNEC) measures in curbing national examination malpractices. Study findings established collusion as a predominant type of abnormality in examination whereas major reason to 
engage in examination irregularity was inadequate individual preparation before examinations. Additionally, foremost contribution through school administrators to curb examination irregularities is by taking part in active supervision during examinations. Further, Otieno [25] cited shame to the students and lowering of school image as some of the effects of examinations irregularities. The study further identified proper student preparation as a major strategy to curb examination anomalies in KCSE. In conclusion, school administrators have potential to strongly eradicate examination irregularities with consideration that they handle it effectively hence attaining country's education goals.

The study made the following recommendations; KNEC to give full assistance and prepare examination officials on examination matters and how to deal with examination misconduct. Secondly is for the school administrators to facilitate intensive preparations of candidates for examinations to enhance their confidence to face it. Thirdly, KNEC was advised to remunerate school administrators for their roles throughout examination period. Fourthly, KNEC should fully enact penalties to persons and centres found guilty of cheating as outlined by the KNEC Bill 2012 so as to prevent others from such malpractices. Finally the study recommended to the Ministry of Education to develop an action plan to aid in elimination of examination irregularities within a specified period of time. Otieno [25] thus proposed a further research to be done on alternative form of assessment in place of high stake KCSE examination. From these findings, universities can embrace some of the recommendations in order to curb examination malpractices.
Rahman, Dangi, Jamaluddin, Mustafa and Yusop [26] assessed Students' Cheating Behaviour in Higher Education System. Findings established that every learning institute have policies/guidelines guiding the administration of examinations. Moi University for instance have guidelines/policies regulating the administration in addition to conduct of students (undergraduate/postgraduate) examinations. Guidelines specify categories of examination irregularities, procedures for dealing with the irregularities and the punishments related to each examination irregularity for example, one or a combination of actions like giving a warning, cancellation of examination results, suspensions for a given time span, or expulsion from the university, depending on the nature of the irregularity committed. The rules and regulations highlight areas that constitute an examination irregularity and consequently, caution students against committing the stated offenses.

Private universities have also developed their examination rules and regulations. For instance University of Eastern Africa, Baraton revised examination rules and regulations 2009, the following among others are well stipulated; that all examinees are expected to be in the examination hall 15 minutes before the indicated time for commencement of the examination, no examinee allowed to have any electronic device in the examination hall and any examinee who breaches the examination rules and regulations shall be required to leave the examination hall, an F grade will be recorded for the course and in addition to the disciplinary action decided by the Academic Standards Committee.

\section{Independent Variable}

\section{Dependent Variable}

\begin{tabular}{|c|c|}
\hline $\begin{array}{l}\text { Existing Regulations and Policies } \\
\text { - Overcrowded examination rooms. } \\
\text { - Poor control of exam booklets. } \\
\text { - Laxity by security personnel. } \\
\text { - Lack of commitment by } \\
\text { invigilators. }\end{array}$ & $\begin{array}{l}\text { Examination Malpractices } \\
\text { - Cheating. } \\
\text { - Fabrication. } \\
\text { - Leakage. } \\
\text { - Assaulting supervisor/invigilator }\end{array}$ \\
\hline
\end{tabular}

Fig-1: Conceptual Framework

\section{RESEARCH METHODOLOGY}

This study adopted mixed methods research design. A mixed method research design is an approach to inquiry that combines both qualitative and quantitative forms [27]. The The target population comprised all the Universities in Kenya; 31 Public and 33 Private Universities, a total of 64 universities formed the target for this study, refer to Appendix V. All the universities have a siting capacity of over 800,000 students per academic year. Participants comprised of undergraduate students, Dean of Students (DoSs), Lecturers, Examination Officers (EOs) and Heads of Department (HoDs) from each of the Universities. The researcher used $10 \%$ of the universities as the sample size and thus 6 universities were the sample size.

The sample size was chosen in acknowledgment of the five sets of study units (students, lecturers, HoDs, DoSs and EOs). For the purpose of this study Raosoft, Inc. online sample size 
Stellah J. Keter., J Adv Educ Philos, Jan, 2021; 5(1): 1-15

calculator was used to determine the sample size of students; at confidence level of $95 \%$ and a margin of error of 5\% was accepted since it is a common choice, and a response distribution at $50 \%$ as explained by Omair [28]. Since the students' target population was 83,748 the sample size from Raosoft, Inc. online sample size calculator was 383 respondents. The lecturers target population was $2,125,20 \%$ of the target population was used. Mugenda and Mugenda [29] justifies that $10 \%-30 \%$ as a representative target populace and for this study $20 \%$ was used because it will give the study a reasonable presentation of the lecturers in the six universities. One (1) DoS and one (1) EO from each of the six universities were purposely selected. Further two (2) HoDs were selected from each university. Therefore the total sample size for this study was four hundred and fifty (450) respondents as indicated in Table-1.

Table-1: Sample size

\begin{tabular}{|l|l|l|l|l|l|l|l|l|l|}
\hline U & S & n & FGD(n) & LEC & n & DoS (n) & E O (n) & HoD (n) & Total (n) \\
\hline A & 47458 & 176 & 12 & 875 & 18 & 1 & 1 & 2 & 209 \\
\hline B & 4760 & 18 & 12 & 273 & 5 & 1 & 1 & 2 & 40 \\
\hline C & 3600 & 14 & 12 & 140 & 3 & 1 & 1 & 2 & 33 \\
\hline D & 8152 & 30 & 12 & 175 & 4 & 1 & 1 & 2 & 50 \\
\hline E & 9468 & 35 & 12 & 352 & 7 & 1 & 1 & 2 & 58 \\
\hline F & 10,310 & 38 & 12 & 310 & 6 & 1 & 1 & 2 & 60 \\
\hline TOTAL & 83748 & $\mathbf{3 1 1}$ & $\mathbf{7 2}$ & 2125 & $\mathbf{4 3}$ & $\mathbf{6}$ & $\mathbf{6}$ & $\mathbf{1 2}$ & $\mathbf{4 5 0}$ \\
\hline
\end{tabular}

RESEARCH FINDINGS AND DISCUSSIONS

Policies Related To Examination Malpractices among Undergraduate Students

The objective of this study was to evaluate policies related to examination malpractices among undergraduate students in Kenyan universities. The findings of this objective are presented and discussed in Table-2.

Table-2: Attaining Minimum Mark of 40 Makes Students Engage in Examination Malpractices

\begin{tabular}{|l|l|l|l|}
\hline Respondents & Undergraduates public & Undergraduates private & Lecturers \\
\hline & $\mathrm{F}(\%)$ & $\mathrm{F}(\%)$ & $\mathrm{F}(\%)$ \\
\hline SD & $6(2.4)$ & $0(0.0)$ & $7(18.4)$ \\
\hline $\mathrm{D}$ & $24(9.6)$ & $28(80.0)$ & $9(23.7)$ \\
\hline $\mathrm{UD}$ & $8(3.2)$ & $2(5.7)$ & $5(13.2)$ \\
\hline A & $121(48.6)$ & $3(8.6)$ & $8(21.1)$ \\
\hline SA & $90(36.2)$ & $2(5.7)$ & $9(23.7)$ \\
\hline Mean & $4.07(81.3)$ & $2.40(48.0)$ & $3.08(61.6)$ \\
\hline Std. Dev & 0.993 & 0.881 & 1.477 \\
\hline
\end{tabular}

Responses from students in public universities as shown in Table-2 indicate that majority $84.8 \%$ agreed, $12.0 \%$ disagreed and $3.2 \%$ were undecided that attaining minimum mark of 40 percent makes students engage in examination malpractices. The study found that at $81.3 \% \quad$ (mean=4.07 and Std Dev=0.993) respondents accepted that attaining minimum mark of 40 makes students engage in examination malpractices. Similarly, responses from students in private universities indicate that majority $80.0 \%$ disagreed, $14.3 \%$ agreed and $5.7 \%$ were undecided that attaining minimum mark of 40 makes students engage in examination malpractices. The study found that at $48.0 \%$ (mean=2.4 and Std Dev=0.881) of respondents gave their opinion that attaining minimum mark of 40 makes students engage in examination malpractices. The findings indicate that there is a disparity between the views on whether attaining a minimum mark of 40 percent makes students engage in examination malpractices. This is revealed by a majority of undergraduates in public universities who agreed $(84.8 \%)$ and majority in private universities who disagreed $(80.0 \%)$ about the statement. This implies that the minimum pass marks are not uniform for the two categories of universities. It emerged in one of the focused group discussions that the high grading system contributes to academic malpractices. In one of the private university a student must score a minimum of $\mathrm{C}+$ in a major course and a minimum of a $\mathrm{C}$ in a common course. The participants in the group further explained how students will engage to cheat in CATs because there is a belief by students that if you pass in the CAT then definitely you will pass in the final examination.

In these institutions more weight is given to CATs than the main examination. Contrary some other focused group discussion participants disagreed that the 
Stellah J. Keter., J Adv Educ Philos, Jan, 2021; 5(1): 1-15

pass mark of $40 \%$ is not too high for them to contribute to examination malpractices. In these institutions the CATs constitute $30 \%$ and the main examination $70 \%$. They attributed the malpractices to factors such as lack of preparedness to face the examination and failing to attend lecturers. Further the same students acknowledged that the $40 \%$ pass mark is lower that many students assume that attaining the mark might be easy but to discover that it is not easy to attain if one is not well prepared. Majority of the lecturers (44.8\%) agreed that attaining a minimum mark of 40 percent makes students engage in examination malpractices, $32.1 \%$ disagreed and $13.2 \%$ were undecided with the statement. $61.6 \%$ (mean=3.08 and Std Dev=1.477) of respondents accepted that attaining minimum mark of 40 makes students engage in examination malpractices. The fact that majority of the lecturers agreed at lower percentage, implies that the attainment of a minimum mark $40 \%$ do no strongly contribute to students engaging in examination malpractices.

Table-3: Overcrowded Examination Rooms Tempt Students to Cheat in Examination

\begin{tabular}{|l|l|l|l|}
\hline Respondents & Undergraduates public & Undergraduates private & Lecturers \\
\hline & $\mathrm{F}(\%)$ & $\mathrm{F}(\%)$ & $\mathrm{F}(\%)$ \\
\hline SD & $6(2.4)$ & $1(2.9)$ & $2(5.3)$ \\
\hline $\mathrm{D}$ & $19(7.6)$ & $3(8.6)$ & $0(0.0)$ \\
\hline $\mathrm{UD}$ & $23(9.2)$ & $4(11.4)$ & $1(2.6)$ \\
\hline A & $118(47.4)$ & $19(54.3)$ & $19(50.0)$ \\
\hline SA & $83(33.3)$ & $8(22.9)$ & $16(42.1)$ \\
\hline Mean & $4.01(80.3)$ & $3.86(77.1)$ & $4.24(84.7)$ \\
\hline Std. Dev & 0.973 & 0.974 & 0.943 \\
\hline
\end{tabular}

From Table-3 majority $(80.7 \%)$ of undergraduate students in public universities agreed that overcrowded examination rooms tempt students to cheat in examination $10.0 \%$ disagreed and $9.2 \%$ were undecided with the statement. The study found that at $80.3 \%$ (mean=4.01 and Std Dev=0.973) respondents accepted that overcrowded examination rooms tempt students to cheat in examination. Response from undergraduate students in private universities indicate that majority $77.2 \%$ agreed, $11.5 \%$ and $11.4 \%$ were undecided disagreed with the statement that overcrowded examination rooms tempt students to cheat in examination. The study respondents accepted at $77.1 \% \quad($ mean=3.86 and Std Dev=0.974) that overcrowded examination rooms tempt students to cheat in examination.

Lecturers also agreed that overcrowded examination rooms tempt students to cheat in examination. This is evidenced by majority of the lecturers $92.1 \%$ who agreed, $5.3 \%$ who disagreed and $2.6 \%$ were undecided that overcrowded examination rooms tempt students to cheat in examination. $84.7 \%$ (mean=4.24 and Std Dev=0.943) of respondents accepted that overcrowded examination rooms tempt students to cheat in examination. This implies that when students are seated close to one another in an examination room it becomes very difficult for the invigilators to have control over them. Even if an invigilator identifies students cheat, it becomes impossible for the same invigilator to reach the cheating student because of the congestion. As a result the student shall have hidden the materials before the invigilator reaches him/her.

The findings are in agreement with Ifijeh et al., [30] who identified that overcrowded sitting arrangement and other causes which include the fear of failure, craze for certificate, desire of parents to have their children in choice professions and university and pressure on students to pursue courses for which they have no aptitude and pressure on teachers who want to gain favour of student contribute to examination cheating. Further, Ifijeh et al., [30] add that overcrowded examination classroom/halls can enable students to steal examinations and it is a design of corrupt school officials to use classrooms instead of a hall in the conduct of public examinations because they want to aid the same students cheat and they are paid a fee for that.

Table-4: Non Customized Examination Booklets is a Temptation to Cheat

\begin{tabular}{|l|l|l|l|}
\hline Respondents & Undergraduates public & Undergraduates private & Lecturers \\
\hline & $\mathrm{F}(\%)$ & $\mathrm{F}(\%)$ & $\mathrm{F}(\%)$ \\
\hline $\mathrm{SD}$ & $8(3.2)$ & $1(2.9)$ & $2(5.3)$ \\
\hline $\mathrm{D}$ & $24(9.6)$ & $5(14.3)$ & $3(7.9)$ \\
\hline $\mathrm{UD}$ & $18(7.2)$ & $0(0.0)$ & $4(10.5)$ \\
\hline $\mathrm{A}$ & $111(44.6)$ & $16(45.7)$ & $20(52.6)$ \\
\hline SA & $88(35.3)$ & $13(37.1)$ & $9(23.7)$ \\
\hline Mean & $4.00(79.9)$ & $4.00(80.0)$ & $3.82(76.3)$ \\
\hline Std. Dev & 1.053 & 1.111 & 1.062 \\
\hline
\end{tabular}


Stellah J. Keter., J Adv Educ Philos, Jan, 2021; 5(1): 1-15

It can be observed from Table-4 that non customized examination booklets contribute to academic malpractices. This is shown by $79.9 \%$ of students in public universities who agreed, $12.8 \%$ disagreed and the rest $7.2 \%$ were undecided. The study found that at $79.9 \%$ (mean=4.00 and Std Dev=1.053) respondents accepted that non customized examination booklets is a temptation to cheat. Further, findings from undergraduate students in private universities show that $82.8 \%$ agreed and $17.2 \%$ disagreed that non customized examination booklets are a temptation to cheat. The study findings accepted at $80.0 \%$ (mean $=4.00$ and Std Dev=1.111) that non customized examination booklets is a temptation to cheat. The findings indicate that students from both public and private universities agree that non customized booklets contribute to academic malpractice. Lecturers also support the statement that non customized examination booklets is a temptation to students to cheat. This is shown by a majority $76.3 \%$ who agreed, $13.2 \%$ who disagreed and $10.5 \%$ who were undecided with the statement. Respondents accepted at $76.3 \%$ (mean=3.82 and Std Dev=1.063) that non customized examination booklets is a temptation to cheat. The findings are in agreement with Starovoytova and Arimi [31], who found that during marking of the examinations some strange booklets may be traced. This may be witnessed by the presence of examination booklets with serial numbers beyond the range used during that particular examination. It is an indication that some students could possibly be doing their examinations elsewhere and bring the answer booklets to examination room for submission.

Table-5: Lack of Strict Control of Class Attendance Lists Contribute to Examination Malpractice

\begin{tabular}{|l|l|l|l|}
\hline Respondents & Undergraduates public & Undergraduates private & Lecturers \\
\hline & $\mathrm{F}(\%)$ & $\mathrm{F}(\%)$ & $\mathrm{F}(\%)$ \\
\hline $\mathrm{SD}$ & $6(2.4)$ & $0(0.0)$ & $0(0.0)$ \\
\hline $\mathrm{D}$ & $31(12.5)$ & $5(14.3)$ & $6(15.8)$ \\
\hline $\mathrm{UD}$ & $22(8.8)$ & $1(2.9)$ & $0(0.0)$ \\
\hline $\mathrm{A}$ & $126(50.6)$ & $15(42.9)$ & $15(39.5)$ \\
\hline SA & $64(25.7)$ & $14(40.0)$ & $17(44.7)$ \\
\hline Mean & $3.85(77.0)$ & $4.09(81.7)$ & $4.13(82.6)$ \\
\hline Std. Dev & 1.017 & 1.011 & 1.044 \\
\hline
\end{tabular}

The findings of undergraduate students in public universities reveal that lack of strict control of class attendance contribute to examination malpractices. This is evidenced by majority $(76.3 \%)$ of the respondents who agreed, $14.9 \%$ who disagreed and $8.8 \%$ who were undecided with the statement that lack of strict class attendance lists controls contribute to examination malpractice. The study found that at $77.0 \%$ (mean=3.85 and Std Dev=1.017) respondents accepted that lack of strict control of class attendance lists have contributed to examination malpractices. Also, findings from undergraduate students in private universities reveal that majority $(82.9 \%)$ agreed, $14.3 \%$ disagreed and $2.9 \%$ were undecided that lack of strict control of class attendance lists contributes to examination malpractice. Students accepted at $81.7 \%$ (mean $=4.09$ and Std Dev=1.011) that lack of strict class attendance lists controls contribute to examination malpractice.
Lecturers were of the opinion that lack of strict control of class attendance lists contribute to examination malpractice. This is shown by majority of the respondents $(84.2 \%)$ who agreed and $15.8 \%$ who disagreed with the statement that lack of strict class attendance lists controls contribute to examination malpractice. Lecturers accepted at $82.6 \%$ (mean $=4.13$ and Std Dev=1.044) that lack of strict class attendance lists controls contribute to examination malpractice. This could be as a result of the huge classes managed by lecturers which make it impossible for them to monitor the attendance list. As a result students sign class attendance on behalf of their colleagues who are not in class. This habit continues for some students throughout the semester and when the same students come to sit for examination they lack enough content and thus engage in dubious means in order to pass like their counterparts who have been attending classes.

Table-6: Lack of Proper Students' Records Make Students to Lie

\begin{tabular}{|l|l|l|l|}
\hline Respondents & Undergraduates public & Undergraduates private & Lecturers \\
\hline & $\mathrm{F}(\%)$ & $\mathrm{F}(\%)$ & $\mathrm{F}(\%)$ \\
\hline SD & $5(2.0)$ & $1(2.9)$ & $0(0.0)$ \\
\hline D & $26(10.4)$ & $5(14.3)$ & $10(26.3)$ \\
\hline UD & $13(5.2)$ & $0(0.0)$ & $4(10.5)$ \\
\hline A & $120(48.2)$ & $25(71.4)$ & $15(39.5)$ \\
\hline SA & $85(34.1)$ & $4(11.4)$ & $9(23.7)$ \\
\hline Mean & $4.02(80.5)$ & $3.74(74.9)$ & $3.61(72.1)$ \\
\hline Std. Dev & 0.993 & 0.95 & 1.128 \\
\hline
\end{tabular}


Stellah J. Keter., J Adv Educ Philos, Jan, 2021; 5(1): 1-15

Table- 6 show that majority of undergraduate students in public universities $82.3 \%$ agreed, $5.2 \%$ were undecided and $12.4 \%$ disagreed with the statement that lack of proper students' records make students to lie. The study found that at $80.5 \%$ (mean $=4.02$ and Std $\mathrm{Dev}=0.993$ ) respondents accepted that lack of proper students' records makes students to lie. Undergraduates from private universities agreed with a majority $82.8 \%$ who agreed and $17.2 \%$ disagreed that lack of proper students' records make students to lie. $74.9 \%$ (mean=3.74 and Std Dev=0.950) of respondents gave their opinion that lack of proper students' records makes students to lie. Lecturers were asked the same question and their findings indicate that majority $63.2 \%$ agreed, $10.5 \%$ were undecided and $26.3 \%$ disagreed with the statement that lack of proper students' records makes students to lie. $72.1 \%$ (mean=3.61 and Std Dev=1.128) of respondents accepted that lack of proper students' records makes students to lie. This could mean that when students realize that there are no proper records regarding their marks, they claim for marks for some courses which they have never wrote a term paper or sat for examinations. Some students may threaten or bribe the concerned personnel for marks are unearned for.

Table-7: Poor Control of Examination Booklets Tempt Students to Cheat

\begin{tabular}{|l|l|l|l|}
\hline Respondents & Undergraduates public & Undergraduates private & Lecturers \\
\hline & $\mathrm{F}(\%)$ & $\mathrm{F}(\%)$ & $\mathrm{F}(\%)$ \\
\hline SD & $13(5.2)$ & $0(0.0)$ & $3(7.9)$ \\
\hline $\mathrm{D}$ & $22(8.8)$ & $1(2.9)$ & $7(18.4)$ \\
\hline UD & $27(10.8)$ & $1(2.9)$ & $3(7.9)$ \\
\hline A & $102(41.0)$ & $18(51.4)$ & $14(36.8)$ \\
\hline SA & $85(34.1)$ & $15(42.9)$ & $11(28.9)$ \\
\hline Mean & $3.90(77.9)$ & $4.34(86.9)$ & $3.61(72.1)$ \\
\hline Std. Dev & 1.129 & 0.684 & 1.306 \\
\hline
\end{tabular}

It can be observed from the Table-7 that majority of the undergraduate students in public universities $(75.1 \%)$ agreed, $14.0 \%$ disagreed and $10.8 \%$ were undecided with the statement that poor control of examination booklets tempt students to cheat. The study found that at $77.9 \%$ (mean $=3.90$ and Std Dev=1.129) respondents accepted that there is poor control of examination booklets that tempt students to cheat. Also majority of the undergraduate students in private universities $94.3 \%$ agreed that poor control of examination booklets tempt students to cheat, $2.9 \%$ were undecided and $2.9 \%$ disagreed with the statement. The study found that at $86.9 \%$ (mean $=4.34$ and Std $\mathrm{Dev}=0.684$ ) respondents gave their opinion that poor control of examination booklets tempt students to cheat.
Lecturers further agreed that poor control of examination booklets tempt students to cheat since students can swap examination booklets to get answers from their colleagues or exchange the empty examination booklets that are issued in examination room with the already filled examination booklets. This is evidenced by majority of the lecturers $(65.7 \%)$ who agreed that poor control of examination booklets tempt students to cheat, $28.3 \%$ who disagreed and $7.9 \%$ who were undecided with statement. The study found that at $72.1 \%$ (mean=3.61 and Std Dev=1.306) respondents accepted that poor control of examination booklets tempt students to cheat.

Table-8: Low Lecturer/Student Ratio

\begin{tabular}{|l|l|l|l|}
\hline Respondents & Undergraduates public & Undergraduates private & Lecturers \\
\hline & $\mathrm{F}(\%)$ & $\mathrm{F}(\%)$ & $\mathrm{F}(\%)$ \\
\hline $\mathrm{SD}$ & $7(2.8)$ & $0(0.0)$ & $2(5.3)$ \\
\hline $\mathrm{D}$ & $36(14.5)$ & $8(22.9)$ & $4(10.5)$ \\
\hline $\mathrm{UD}$ & $11(4.4)$ & $3(8.6)$ & $1(2.6)$ \\
\hline A & $130(52.2)$ & $20(57.1)$ & $11(28.9)$ \\
\hline SA & $65(26.1)$ & $4(11.4)$ & $20(52.6)$ \\
\hline Mean & $3.84(76.8)$ & $3.57(71.4)$ & $4.13(82.6)$ \\
\hline Std. Dev & 1.061 & 0.979 & 1.212 \\
\hline
\end{tabular}

The findings in Table- 8 show that the undergraduate students from public university agreed that low lecturer/student ration during invigilation of examinations contribute to examination malpractices.
This is evidenced by the majority $(78.3 \%)$ who agreed, $17.3 \%$ who disagreed and $4.4 \%$ were undecided with the statement. The study found that at $76.8 \%$ (mean=3.84 and Std Dev=1.061) respondents accepted 
Stellah J. Keter., J Adv Educ Philos, Jan, 2021; 5(1): 1-15

that there exist low lecturer/student ration during invigilation of examinations and this has given an opportunity for students to propagate cheating. Undergraduate students from private universities also agreed that low lecturer/student ration during invigilation of examinations contribute to examination malpractices. This is evidenced by majority $(68.5 \%)$ of the responses who agreed, $22.9 \%$ who disagreed and $8.6 \%$ who were undecided with the statement. the study accepted at $71.4 \%($ mean $=3.57$ and Std Dev=0.979) that low lecturer/student ration during invigilation of examinations attribute to examination malpractices. Lecturers also gave their opinion on whether Low lecturer/student ration during invigilation of examinations contribute to examination malpractices. The findings indicate that majority of the lecturers $81.5 \%$ agreed, $15.8 \%$ disagreed and $2.6 \%$ were undecided with the statement. The study accepted at $82.6 \% \quad($ mean $=4.13$ and Std Dev=1.212) low lecturer/student ration during invigilation of examinations contribute to examination malpractices.

Table-9: Lack of Surveillance Devices Tempt Students to Cheat

\begin{tabular}{|l|l|l|l|}
\hline Respondents & Undergraduates public & Undergraduates private & Lecturers \\
\hline & $\mathrm{F}(\%)$ & $\mathrm{F}(\%)$ & $\mathrm{F}(\%)$ \\
\hline $\mathrm{SD}$ & $11(4.4)$ & $3(8.6)$ & $0(0.0)$ \\
\hline $\mathrm{D}$ & $26(10.4)$ & $8(22.9)$ & $3(7.9)$ \\
\hline $\mathrm{UD}$ & $23(9.2)$ & $1(2.9)$ & $3(7.9)$ \\
\hline A & $117(47.0)$ & $12(34.3)$ & $14(36.8)$ \\
\hline SA & $72(28.9)$ & $11(31.4)$ & $18(47.4)$ \\
\hline Mean & $3.86(77.2)$ & $3.57(71.4)$ & $4.24(84.7)$ \\
\hline Std. Dev & 1.082 & 1.378 & 0.913 \\
\hline
\end{tabular}

The study findings reveal that majority of the undergraduate students from public universities (75.9\%) agreed that lack of surveillance devices tempt students to cheat, $14.8 \%$ disagreed and $9.2 \%$ were undecided with the statement. The study found that at $77.2 \%$ (mean=3.85 and Std Dev=1.082) respondents accepted that lack of surveillance devices tempt students to cheat in examination. Undergraduate students in private universities agreed also that lack of surveillance devices tempt students to cheat in examination. The findings from the table show that $65.7 \%$ agreed that statement that lack of surveillance devices tempt students to cheat in examination, $31.5 \%$ disagreed and $2.9 \%$ were undecided with the statement.
The study respondents accepted at $71.4 \%$ (mean=3.84 and Std Dev=1.374) that lack of surveillance devices tempt students to cheat in examination. Lecturers revealed that lack of surveillance devices tempt students to cheat in examination since the use of CCTVs can monitor the progression of examination thus students fear to be captured when cheating in examination. This is evidenced by majority of the lecturers $(84.2 \%)$ who agreed with the statement that lack of surveillance devices tempt students to cheat in examination, $7.9 \%$ were undecided and $7.9 \%$ disagreed with the statement. The study findings indicated that $84.7 \%$ (mean $=4.24$ and Std Dev=0.913) of respondents accepted that lack of surveillance devices tempt students to cheat.

Table-10: Laxity by Security Personnel during Examinations

\begin{tabular}{|l|l|l|l|}
\hline Respondents & Undergraduates public & Undergraduates private & Lecturers \\
\hline & $\mathrm{F}(\%)$ & $\mathrm{F}(\%)$ & $\mathrm{F}(\%)$ \\
\hline $\mathrm{SD}$ & $11(4.4)$ & $0(0.0)$ & $4(10.5)$ \\
\hline $\mathrm{D}$ & $32(12.9)$ & $1(2.9)$ & $12(31.6)$ \\
\hline $\mathrm{UD}$ & $18(7.2)$ & $1(2.9)$ & $1(2.6)$ \\
\hline A & $130(52.2)$ & $10(28.6)$ & $13(34.2)$ \\
\hline Mean & $58(23.3)$ & $23(65.7)$ & $8(21.1)$ \\
\hline Std. Dev & $3.77(75.5)$ & $4.57(91.4)$ & $3.24(64.7)$ \\
\hline
\end{tabular}

Responses of undergraduate students in public universities reveal that majority $(75.5 \%)$ agreed, $(17.3 \%)$ disagreed and $(7.2 \%)$ were undecided with the statement that laxity by security personnel during examinations contributes to examination malpractices. The study found at $75.5 \% \quad$ (mean $=3.77$ and Std $\mathrm{Dev}=1.076$ ) that respondents accepted that laxity by security personnel has contributed to cheating during examination. Undergraduate students in private universities also agreed that laxity by security personnel during examinations contribute to examination cheating. This is evidenced by the majority of the responses $(94.3 \%)$ who agreed, $2.9 \%$ were undecided and $2.9 \%$ disagreed with the statement that laxity by 
Stellah J. Keter., J Adv Educ Philos, Jan, 2021; 5(1): 1-15

security personnel during examinations contributes to examination malpractice. The findings of the responses accepted at $91.4 \%$ (mean=4.57 and Std Dev=0.698) that laxity by security personnel during examinations contribute to examination malpractice.

Lecturers concurred with the findings of students that laxity by security personnel during examinations contribute to examination malpractice. The security personnel who are given the mandate of looking after the proceeds of examinations are expected to be very active watching students' movements but their laxity in the course can enable students to cheat in examination. This is evidenced by majority $(55.3 \%)$ who agreed that laxity by security personnel during examinations contribute to examination malpractice, this was followed by $42.1 \%$ who disagreed and $2.6 \%$ who were undecided and with the statement. The findings of the responses accepted at $64.7 \%$ (mean=3.24 and Std Dev=1.384) that laxity by security personnel during examinations contributes to academic malpractices. The security personnel may have the notion that matters that relate to examinations should only be handled by the academic staffs. As a result students take advantage of sneaking out the booklets and to some extent assault the invigilators/ supervisors because they cannot be easily held up.

Table-11: Lack of Commitment by Invigilators / Supervisors during Examination Encourage Cheating

\begin{tabular}{|l|l|l|l|}
\hline Respondents & Undergraduates public & Undergraduates private & Lecturers \\
\hline & $\mathrm{F}(\%)$ & $\mathrm{F}(\%)$ & $\mathrm{F}(\%)$ \\
\hline $\mathrm{SD}$ & $18(7.2)$ & $0(0.0)$ & $0(0.0)$ \\
\hline $\mathrm{D}$ & $16(6.4)$ & $2(5.7)$ & $11(28.9)$ \\
\hline UD & $28(11.2)$ & $3(8.6)$ & $0(0.0)$ \\
\hline A & $112(45.0)$ & $13(37.1)$ & $14(36.8)$ \\
\hline SA & $75(30.1)$ & $17(48.6)$ & $13(34.2)$ \\
\hline Mean & $3.85(77.0)$ & $4.29(85.7)$ & $3.76(75.3)$ \\
\hline Std. Dev & 1.14 & 0.86 & 1.218 \\
\hline
\end{tabular}

In Table-12, undergraduate students in public universities agreed that lack of commitment by invigilators/ supervisors during examination encourage cheating. The findings reveal that majority $75.1 \%$ agreed, $13.6 \%$ disagreed and $11.2 \%$ were undecided with the statement. The study found that at $77.0 \%$ (mean=3.85 and Std Dev=1.140) respondents accepted that lack of commitment by invigilators/ supervisors during examination encourage cheating. Responses from undergraduate students in private universities also agree that lack of commitment by invigilators/ supervisors during examination encourage cheating. The findings reveal that majority $85.7 \%$ agreed, $8.6 \%$ were undecided and $5.7 \%$ disagreed with the statement. The study found that $85.7 \% \quad$ (mean $=4.29$ and Std Dev=0.860) of respondents accepted that lack of commitment by invigilators/ supervisors during examination encourage cheating.
Lecturers in their views agreed that lack of commitment by invigilators/ supervisors during examination encourage cheating. This is evidenced by majority $(71.0 \%)$ who agreed that lack of commitment by invigilators/ supervisors during examination encourage cheating and $28.9 \%$ disagreed with the statement. The study found that $75.3 \%$ (mean $=3.76$ and Std Dev=1.218) of lecturers accepted that lack of commitment by invigilators/ supervisors during examination encourage cheating. One of the respondents during an interview was quoted saying;

'Some invigilators engage in other activities such as reading newspapers and browsing their phones and thus allowing conducive environment for the students to cheat'

This is an implication that when students realize the non-seriousness among the invigilators during examination a conducive environment is created for them to cheat because the invigilators will not keenly observe what the students are doing.

Table-10: Improper Allocation of Examination Rooms Encourage Cheating

\begin{tabular}{|l|l|l|l|}
\hline Respondents & Undergraduates public & Undergraduates private & Lecturers \\
\hline & $\mathrm{F}(\%)$ & $\mathrm{F}(\%)$ & $\mathrm{F}(\%)$ \\
\hline SD & $11(4.4)$ & $0(0.0)$ & $0(0.0)$ \\
\hline $\mathrm{D}$ & $35(14.1)$ & $3(8.6)$ & $5(13.2)$ \\
\hline $\mathrm{UD}$ & $23(9.2)$ & $3(8.6)$ & $3(7.9)$ \\
\hline A & $120(48.2)$ & $15(42.9)$ & $19(50.0)$ \\
\hline SA & $60(24.1)$ & $14(40.0)$ & $11(28.9)$ \\
\hline Mean & $3.74(74.8)$ & $4.14(82.9)$ & $3.95(78.9)$ \\
\hline Std. Dev & 1.106 & 0.912 & 0.957 \\
\hline
\end{tabular}


Stellah J. Keter., J Adv Educ Philos, Jan, 2021; 5(1): 1-15

The study findings on the existing examination policies further revealed that majority of undergraduate students in public universities agree that improper allocation of examination rooms encourage cheating. This is evidenced by $72.3 \%$ who agreed, $18.5 \%$ who disagreed and $9.2 \%$ were undecided with the statement that improper allocation of examination rooms encourage cheating. The study found that at $74.8 \%$ (mean=3.74 and Std Dev=1.106) respondents accepted that improper allocation of examination rooms encourage cheating. Undergraduate students in private universities opined that improper allocation of examination rooms encourage cheating. The findings reveal that majority of the students $(82.9 \%)$ agreed, $8.6 \%$ were undecided and $8.6 \%$ disagreed with the statement that improper allocation of examination rooms encourage cheating. The study found that at $82.9 \%$ (mean=4.14 and Std Dev=0.912) of respondents the respondents accepted that improper allocation of examination rooms encourage cheating. Lecturers reveal that improper allocation of examination rooms encourage cheating and this is evident when large numbers of students are allocated small examination halls which can encourage cheating since there is limited space to distance students from each other. The findings shows that majority of the lecturers (79.8\%) agreed, $13.2 \%$ disagreed and $7.9 \%$ were undecided that improper allocation of examination rooms encourage cheating. The study found that at $78.9 \%$ (mean $=3.95$ and Std Dev=0.957) of respondents accepted that improper allocation of examination rooms encourage cheating.

Table-14: Lack of Timely Release of Examination Results Encourage Cheating

\begin{tabular}{|l|l|l|l|}
\hline Respondents & Undergraduates public & Undergraduates private & Lecturers \\
\hline & $\mathrm{F}(\%)$ & $\mathrm{F}(\%)$ & $\mathrm{F}(\%)$ \\
\hline SD & $27(10.8)$ & $5(14.3)$ & $8(21.1)$ \\
\hline $\mathrm{D}$ & $54(21.7)$ & $2(5.7)$ & $5(13.2)$ \\
\hline UD & $50(20.1)$ & $4(11.4)$ & $1(2.6)$ \\
\hline A & $59(23.7)$ & $14(40.0)$ & $14(36.8)$ \\
\hline SA & $59(23.7)$ & $10(28.6)$ & $10(26.3)$ \\
\hline Mean & $3.27(65.5)$ & $3.63(72.6)$ & $3.34(66.8)$ \\
\hline Std. Dev & 1.331 & 1.352 & 1.529 \\
\hline
\end{tabular}

Finally, the findings of undergraduate students in public universities on the statement that lack of timely release of examination results encourage cheating reveal majority $(47.4 \%)$ disagreed $(32.5 \%)$ agreed and $20.1 \%$ were undecided that lack of timely release of examination results encourage cheating. The study found that at $65.5 \% \quad($ mean $=3.27$ and Std Dev=1.331) respondents accepted that lack of timely release of examination results encourage cheating. Contrary, undergraduate students in private universities agree that lack of timely release of examination results encourage cheating. This is evidenced by majority of the students $(68.6 \%)$ who agreed, $22.0 \%$ who disagreed and $11.4 \%$ who were undecided with the statement that lack of timely release of examination results encourage cheating. The study found that at $72.6 \%$ (mean $=3.63$ and Std Dev=1.352) of respondents gave their opinion that lack of timely release of examination results encourage cheating.

Lecturers also agreed that lack of timely release of examination results encourage cheating. This implies that students need time to prepare for their examination and therefore early release of examination timetable will allow students get enough time to study and prepare for the coming examinations. This is evident by majority of the respondent from lecturers where $63.1 \%$ agreed, $34.3 \%$ disagreed and $2.6 \%$ were undecided on the statement that lack of timely release of examination results encourage cheating. The study found that at $66.8 \% \quad($ mean=3.34 and Std Dev=1.529) respondents accepted that lack of timely release of examination results encourage cheating. The study findings of this objective therefore have revealed that in all the sampled universities there are examination policies in place but students still engage in examination malpractices. One of the Dean of students explained the procedure followed when a student(s) is got cheating.

"The chief invigilator fills the form and signs it, the cheating student(s) is also required to fill and sign the same form, and later the student faces the academic standards committee for consequent disciplinary action as stated in the policy".

Thus majority of the undergraduate students from public universities accepted that attaining minimum mark of 40 makes students engage in examination malpractices, overcrowded examination rooms tempt students to cheat in examination and lack of proper students' records make students to lie. Policies adopted by the universities have direct impact on students' decision on how performance in examinations can be achieved. The 40 mark rule might not make other students to work extra hard in class but rather solicit to cheating. The inability of the university to build large examination halls that result to congestion and overcrowding in examination halls, this can enable 
Stellah J. Keter., J Adv Educ Philos, Jan, 2021; 5(1): 1-15

students with ill minded intentions to cheat in an examination.

The study results revealed that majority of the undergraduate students from private universities accepted that laxity by security personnel during examinations, lack of commitment by invigilators/ supervisors during examination encourage cheating, lack of strict class attendance lists controls and noncustomized examination booklets is a temptation to cheat. This implies that if the security personnel fail to do their job well students can easily get chances to smuggle in or out of the examination hall or assault the invigilators in the process of being arrested. Another policy which contributes to examination malpractices is lack of strict rules on class attendance which implies that universities' academic departments should liaise with various schools and departments on how best the class attendance can be strictly managed to enhance students' attendance to class. The study results further showed that majority of the respondents (lecturers) accepted that overcrowded examination rooms tempt students to cheat in examination. This implies that most universities in Kenya have examination halls that are congested during examination time and this encourages students to cheat in examination. Lack of surveillance devices in examination halls tempt students to cheat and Lack of strict control of class attendance lists.

\section{Inferential Analysis}

Inferential analysis was conducted in order to determine the existence of aaociat between the study variables.

\section{Correlation Analysis Results}

Table-15: Overall Correlation Analysis Results

\begin{tabular}{|l|l|l|l|}
\hline \multicolumn{2}{|c|}{} & Existing policies & Examination malpractices \\
\hline \multirow{4}{*}{ Existing policies } & Pearson Correlation & 1 & \\
\cline { 2 - 4 } & Sig. (2-tailed) & & \\
\cline { 2 - 4 } & $\mathrm{N}$ & 322 & \\
\hline \multirow{2}{*}{ Examination malpractices } & Pearson Correlation & $.669 * *$ & 1 \\
\cline { 2 - 4 } & Sig. (2-tailed) & 0 & 322 \\
\hline & $\mathrm{N}$ & 322 & \\
\hline \multirow{2}{*}{$* *$ Correlation is significant at the 0.01 level (2-tailed). } & \\
\hline
\end{tabular}

The findings as shown in Table-15 indicate that the existing policies related to examination malpractices has a positive and statistically significant effect on examination malpractices among undergraduate students with $(\mathrm{r}=0.669 ; \mathrm{p}<0.05)$. This implies that the existing policies related to the examination malpractice have great effect on the degree to which students can practice examination cheating. Universities are better advised to adopt good policies that can curb examination malpractices. The findings are supported by Kagete [32] who cited that Kenyatta University 2011/2013 catalogue, in reference to examination irregularity says: "A student who is caught involved in any examination irregularity shall be suspended immediately by the Registrar (Academic) upon receipt of instant report, pending appearance before the Disciplinary Committee". Whereas at the University of Nairobi, a memo from the Acting Registrar Academic dated December 30, 2011 addressed to all students, reminds them of the gravity of cheating in examinations, with reference to both Senate Resolutions Numbers 1913, and 1914 dated 12th July, 1978. Like Kenyatta University, the memo spells out the grave consequences of examination malpractices which include expulsion from the university. All public universities have their own policies regarding the examination but cases of malpractices still emerge.

Patrick [23] also discussed that policies to curb examination malpractices requires engaging in enquiry driven reform and examining the everyday realities of teaching and learning and schooling in order to identify what needs to be fixed and how. And Otieno [25] further posit that school administrators who formulate policies used in curbing examination irregularities has to play an active supervisory role during examinations. The main effect of examination irregularities was found to be: lowering of school reputation and also brought shame to the students. The study found that proper preparation of students for examinations was the main strategy in curbing examination irregularities in KCSE examinations. The findings concluded that the school administrators can effectively eliminate examination irregularities if they play their role effectively hence lead to achievement of education goals of the country.

\section{Multiple Regression Analysis}

The study used multiple linear regression analysis to determine the combined linear relationship between the dependent variable (Examination malpractices among undergraduate students) and the independent variables (Existing policies).

\section{Model Summary Results}

The findings as shown in Table-16 showed that $\left(\mathrm{R}^{2}=0.925\right)$. This implies that there is a positive effect of intervention strategies to curb examination malpractices among undergraduate students and therefore $92.5 \%$ of variation in examination 
Stellah J. Keter., J Adv Educ Philos, Jan, 2021; 5(1): 1-15 malpractices among undergraduate students is accounted by the following strategies; Existing policies

Table-16: Model Summary

\begin{tabular}{|l|l|l|l|l|}
\hline Model & R & R Square & Adjusted R Square & Std. Error of the Estimate \\
\hline $\mathbf{1}$ & $.962^{\mathrm{a}}$ & .925 & .924 & .12118 \\
\hline
\end{tabular}

\section{Fitness of Regression Model}

Analysis of variance was used to determine if the multiple regression models were fit for the data. The results as shown in table 17 indicated that the effect of dependent variable was statistically significant
$(\mathrm{F}=316.421 ; \mathrm{p}<0.05)$. This implied that the multiple regression model was fit for the data, therefore the overall regression model for Existing Policies was statistically significant and affects examination malpractices among undergraduate students.

Table-17: ANOVA Test Results

\begin{tabular}{|l|l|l|l|l|l|l|}
\hline \multicolumn{2}{|l|}{ Model } & Sum of Squares & Df & Mean Square & F & Sig. \\
\hline \multirow{3}{*}{1} & Regression & 48.922 & 4 & 12.231 & 316.421 & $.000^{\mathrm{b}}$ \\
\cline { 2 - 7 } & Residual & 12.253 & 317 & .039 & & \\
\cline { 2 - 7 } & Total & 61.175 & 321 & & & \\
\hline
\end{tabular}

\section{Regression Coefficients}

The T-test of statistical significance of each regression coefficient was conducted in order to determine the beta $(\beta)$ value which shows how strongly each independent variable affects the dependent variable. Table 18 shows results of the study variable; the regression coefficients. The study findings revealed that Existing policies had a positive and statistical significant effect on examination malpractices among undergraduate students $(\beta=0.325 ; \mathrm{p}<0.05)$.

Table-18: Regression Analysis

\begin{tabular}{|c|c|c|c|c|c|}
\hline & \multicolumn{2}{|c|}{ Unstandardized Coefficients } & \multirow{2}{*}{$\begin{array}{l}\text { Standardized Coefficients } \\
\text { Beta }\end{array}$} & \multirow[t]{2}{*}{$\mathbf{t}$} & \multirow[t]{2}{*}{ Sig. } \\
\hline & $\mathrm{B}$ & Std. Error & & & \\
\hline (Constant) & .383 & .107 & & 3.592 & .000 \\
\hline Existing policies & .325 & .019 & .478 & 17.474 & .000 \\
\hline
\end{tabular}

From Table-17, the multiple regression equation can be written as:

$Y=.383+0.325 X_{1}$

The findings can be interpreted as; at constant, existing policies on examination malpractices among undergraduate students was at 0.997 units. The coefficient of 0.325 indicates that an improvement in Existing policies by one unit increases curbing of examination malpractices among undergraduate students by 0.325 units.

\section{Hypotheses Testing}

In this section, the study sort to establish the relationship between the study variables. The study used Pearson correlation analysis to test the relationship between the study variables. All the hypotheses were tested where $\mathbf{p}$ value of less than 0.05 shows there was significant relationship between the variables and null hypotheses were rejected while $\mathbf{p}$ value of more than 0.05 shows there was no significant relationship between study variables and the study fails to reject the null hypothesis.

Table-19: Hypothesis Table

\begin{tabular}{|l|l|l|}
\hline Hypotheses & $\boldsymbol{\beta}$ and P values & $\begin{array}{l}\text { Decision rule } \\
\text { (accept/reject) }\end{array}$ \\
\hline $\begin{array}{l}\mathrm{H}_{01:} \text { There is no statistical significant relationship between the existing } \\
\text { policy related strategies and examination malpractices among } \\
\text { undergraduate students. }\end{array}$ & $\begin{array}{l}\beta_{1}=0.325 ; \\
\mathrm{P}=0.001<0.05\end{array}$ & $\begin{array}{l}\text { Rejected the } \\
\text { null hypothesis }\end{array}$ \\
\hline
\end{tabular}

The hypotheses $\left(\mathbf{H}_{\mathbf{0 2}}\right)$ of the study stated that there is no statistical significant relationship between the existing policies related strategies and examination malpractices among undergraduate students. The study results adopted the alternate hypothesis as shown in Table-19 which indicated that there is statistical significant relationship between the existing policy related strategies and examination malpractices among undergraduate students $\left(\beta_{2}=0.325 ; \mathrm{P}=0.000<0.05\right)$. The $\beta$ factor of 0.325 implies that the existing policy related strategies contribute to examination malpractices among undergraduate students by $32.5 \%$. The p-value of 0.000 is less than the predictable value of 0.05 which indicates that the existing policy related strategies have a positive and statistical significant effect on examination malpractices among undergraduate students in public and private universities in Kenya. The existing policy related strategies to examination 
Stellah J. Keter., J Adv Educ Philos, Jan, 2021; 5(1): 1-15

malpractices have a greater impact in curbing examination malpractices among undergraduate students.

\section{CONCLUSIONS OF THE STUDY}

From the findings of this study it was revealed that most students fail to attend lectures because they engage in other non -academic activities. Some students come from poor family backgrounds and they may not be able to raise adequate finances to pay their fees and meet the living expenses. As a result these students engage in businesses to raise money at the expense of their studies. The study concluded that examination malpractices among undergraduate students include attaining minimum mark of 40 makes, thus students engage in examination malpractices, overcrowded examination rooms tempt students to cheat in examination and lack of proper students' records make students to lie. Laxity by security personnel during examinations, lack of commitment by invigilators/ supervisors during examination encourages cheating, lack of strict class attendance lists controls and noncustomized examination booklets are a temptation to cheat.

\section{RECOMMENDATIONS OF THE STUDY}

The study recommended that universities to enhance work study programmes in which these students can earn money to meet their university costs. Findings indicated that most of the students did not complain of $40 \%$ cut mark while other students complained that a minimum pass mark of $\mathrm{C}+$ in major course and $\mathrm{C}$ in common courses are too high and tempt students to cheat in examination. Further, the study recommended academic departments to review on the minimum pass mark since the policy of minimum mark encourages students to be lazy and definitely engage in examination malpractices. Finally, the study recommended that the DVC and the Registrar in charge of academics to make spot checks during examination as a way of monitoring what is happening during this process of examinations.

\section{REFERENCES}

1. McCormick, R., \& James, M. (2018). Curriculum evaluation in schools. Routledge.

2. Naliaka, P., Odera, P., \& Poipoi, M. (2015). Perceived psycho-social and school factors contributing to malpractices in internal examinations among secondary school students in Kakamega-Central Sub-county: Implications for counseling. International Journal of Psychology and Counselling, 7(2), 18-23.

3. Russo, C. J. (Ed.). (2018). Handbook of Comparative Education Law: Selected European Nations (Vol. 3). Washington DC, US: Rowman \& Littlefield Publishers.

4. Teh, M. K., \& Russo, C. J. (2018). Educational Negligence: Is It a Viable Form of Action?. In The
Palgrave Handbook of Education Law for Schools, 20(1), 39-58.

5. Kasler, J., Hen, M., \& Sharabi-Nov, A. (2018). Academic Integrity in Higher Education: the Case of a Medium-Size College in the Galilee, Israel. Journal of Academic Ethics, 2(5), 1-17.

6. Onuka, A. O., \& Durowoju, E. O. (2013). Stakeholders' role in curbing examination malpractice in Nigeria. International Journal of Economy, Management and social sciences, 2(6), 342-348.

7. Chaminuka, L., \& Ndudzo, D. (2014). Students and Staff Perceptions on Examination Malpractice and Fraud in Higher Education in Zimbabwe. Asian Journal of Humanities and Social Sciences (AJHSS), 2(2), 78-90.

8. Udim, D. K., Abubakar, U., \& Essien, J. O. (2018). An Indepth Evaluation on the Issue of Examination Malpractice in Nigeria. Research in Pedagogy, 8(2), 204-205.

9. Ajzen, I. (1991). The theory of planned behavior. Organizational behavior and human decision processes, 50(2), 179-211.

10. Ajzen, I., \& Fishbein, M. (1975). A Bayesian analysis of attribution processes. Psychological bulletin, 82(2), 261.

11. Alleyne P., \& Phillips, K. (2011). Exploring Academic Dishonesty among University Students in Barbados: an Extension to the Theory of Planned Behaviour. J Acad Ethics, 9(1): 323-338.

12. Mulak, A., \& Bonaz, B. (2015). Brain-gutmicrobiota axis in Parkinson's disease. World journal of gastroenterology: WJG, 21(37), 10609.

13. O'Neill, H. M., \& Pfeiffer, C. A. (2012). The Impact of Honour Codes and Perceptions of Cheating on Academic Cheating Behaviours, Especially for MBA Bound Undergraduates. Accounting Education, 21(3), 231-245.

14. Keter, F. K., \& Darkwa, J. (2012). Perspective: the potential of pyrazole-based compounds in medicine. Biometals, 25(1), 9-21.

15. Carrol, E. D., Thomson, A. P. J., \& Hart, C. A. (2002). Procalcitonin as a marker of sepsis. International journal of antimicrobial agents, 20(1), 1-9.

16. Trafimow, D., Sheeran, P., Conner, M., \& Finlay, K. A. (2002). Evidence that perceived behavioural control is a multidimensional construct: Perceived control and perceived difficulty. British journal of social psychology, 41(1), 101-121.

17. Leach, M., Hennessy, M., \& Fishbein, M. (2001). Perception of Easy-Difficult: Attitude or SelfEfficacy?. Journal of Applied Social Psychology, 31(1), 1-20.

18. Trafimow, D., \& Duran, A. (1998). Some tests of the distinction between attitude and perceived behavioural control. British Journal of Social Psychology, 37(1), 1-14. 
Stellah J. Keter., J Adv Educ Philos, Jan, 2021; 5(1): 1-15

19. Fishbein, T. M., Fiel, M. I., Emre, S., Cubukcu, O., Guy, S. R., Schwartz, M. E., ... \& Sheiner, P. A. (1997). Use of livers with microvesicular fat safely expands the donor pool. Transplantation, 64(2), 248-251.

20. Rhodes, R. E., \& Courneya, K. S. (2003). Investigating multiple components of attitude, subjective norm, and perceived control: An examination of the theory of planned behaviour in the exercise domain. British journal of social psychology, 42(1), 129-146.

21. Coleman, J. S. (1994). Foundations of social theory. Harvard university press.

22. Stone- Romero, E. F., \& Rosopa, P. J. (2010). Research design options for testing mediation models and their implications for facets of validity. Journal of Managerial Psychology.

23. Patrick, N. C. N. (2016). Non-formal Education and the Promise of Development. Java, Indonesia: UNESCO Digital Library.

24. Tambuwal, A. (2013). Rule of Law fundamental for democracy, good governance in Nigeria. Being a paper presented at the annual Mallam Aminu Kano Memorial Lecture in Kano in Kano State Nigeria. Global Journal of Applied, Management and Social Sciences (GOJAMSS), 16(3), 22192234.

25. Otieno, G. B. N. K. (2016). Effectiveness of Kenya National Examinations Council Measures in Curbing National Examination Malpractices in Public Secondary Schools in Kisii
County. International Journal of Scientific

Research and Management, 4(2), 130-144.

26. Rahman, N. H. W. A., Dangi, M. R. M., Jamaluddin, S., Mustafa, L. M., \& Yusop, Y. (2016). Students' Cheating Behaviour in Higher Education System: Reconnoitring the Academic Integrity from the Accounting Students Perspectives. In Regional Conference on Science, Technology and Social Sciences, 1(5), 3-18.

27. Creswell, J. W., \& Clark, V. L. P. (2017). Designing and Conducting Mixed Methods Research. Sage Publications.

28. Omair, A. (2014). Sample size estimation and sampling techniques for selecting a representative sample. Journal of health specialties, 2(4), 142.

29. Mugenda, A. (2003). Research Methods Quantitative and Qualitative Approaches Nairobi, Kenya. Open Access Library Journal, 3(11),1-4

30. Ifijeh, G., Michael-Onuoha, H. C., Ilogho, J. E., \& Osinulu, I. (2015). Emergence of hi-tech examination malpractices in Nigeria: issues and implications. International Journal of Education and Research, 3(3), 113-122.

31. Starovoytova, D., \& Arimi, M. (2017). Witnessing of Cheating-in-Examinations Behavior and Factors Sustaining Integrity. Journal of Education and Practice, 8(10), 127-141.

32. Kagete, P. (2008). Examination malpractices In Kenya. Master of education Thesis in Measurements and Evaluation, in the Faculty of Education. Phys. Rev. 47(3), 777-780. 